\title{
Los derechos humanos en la teología de Ignacio Ellacuría
}

\author{
Alejandro Rosillo Martínez, \\ Universidad Autónoma de San Luis Potosí, \\ México.
}

\section{La relación entre teología y derechos humanos}

Nadie puede ignorar, y mucho menos invisibilizar, los conflictos existentes entre el cristianismo (oficial) y los derechos humanos. Tratándose de textos pontificios, por ejemplo, nos encontramos con posturas contra la libertad en general, y la de conciencia y de religión específicamente: en el Dictatus papae, Gregorio VII declara el poder absoluto y supremo del romano pontífice; en la carta Quod aliquantum, Pío VI afirma que la libertad y la igualdad llevan a la barbarie y que la libertad religiosa es un derecho que atenta contra el plan divino; en la Mirari vos, de Gregorio XVI, se considera un principio disparatado la libertad de conciencia; o la Quanta cura y el Syllabus, donde Pío IX considera a las declaraciones de derechos humanos como incompatibles con la fe cristiana. Ni qué decir de acciones del mismo pontificado contra la ciencia, el pensamiento científico, las investigaciones histórico-críticas, etc. ${ }^{1}$. También se pueden tomar en cuenta las diversas violaciones de derechos humanos que, desde la perspectiva actual, se cometieron durante la Inquisición y sus procedimientos: contra el derecho a la vida, a la integridad y a un juicio justo. En el mismo sentido, las violaciones realizadas en las guerras de religiones, y en la conquista-"evangelización" de los territorios y las personas de los pueblos indígenas de América Latina ${ }^{2}$. A lo anterior podemos sumar la discriminación que se realiza contra la mujer en la Iglesia, las características poco democráticas de las estructuras eclesiales, o las posturas pontificias contra el pluralismo cultural y religioso.

1. Cf. J. J. Tamayo-Acosta, Fundamentalismos y diálogo entre religiones, Trotta, Madrid, 2004, pp. 210-226.

2. Cf. J. Giraldo, Derechos humanos y cristianismo. Transfondos de un conflicto, Universidad Carlos III de Madrid-Dykinson, Madrid, 2008, pp. 19-78. 
Si consideramos, como lo hace Ellacuría, a la teología como el momento intelectual de la praxis eclesial, entonces dichas posturas pontificias y prácticas del cristianismo oficial tuvieron su momento teológico que funcionó como ideología justificatoria de tales violaciones de derechos humanos. En este sentido, por ejemplo, encontramos la teología de Agustín de Hipona, que niega todo derecho al error y justifica la represión contra los herejes; la defensa de la esclavitud natural en contra de los indígenas de América realizada por el pensamiento de Ginés de Sepúlveda; o ciertas teologías contemporáneas contra los derechos de la mujer o de algunas minorías.

Sin dejar de reconocer los conflictos anteriores, existen otras concepciones del cristianismo que se encarnan en prácticas a favor de los derechos humanos. Muchas de estas prácticas nacen, en un primer momento, de la sensibilidad de los cristianos ante las necesidades humanas y ante el clamor de los oprimidos. En América Latina, para nadie es novedad que muchas organizaciones promotoras de derechos humanos se inspiran en el pensamiento cristiano, y que ciertos sectores de la Iglesia católica y de otras iglesias cristianas han mostrado un profundo interés por la justicia: algunas diócesis han creado la pastoral de derechos humanos, órdenes religiosas constituyen o asesoran organizaciones de la sociedad civil (OSC), y algunas instituciones educativas de corte cristiano se han preocupado por la educación en la paz, la justicia y la solidaridad. Sin duda, esta lucha tiene sus antecedentes históricos, como son los casos de fray Bartolomé de las Casas, fray Alonso de la Veracruz, fray Antonio de Montesinos y Vasco de Quiroga, que defendieron la vida y otros bienes y derechos de los indígenas de las tierras recién invadidas y conquistadas.

Muchos de los movimientos cristianos a favor de la justicia y derechos humanos han tenido como su momento intelectual a la Teología de la Liberación, de la cual Ellacuría fue uno de sus principales autores, sobre todo durante la etapa de crecimiento y consolidación de esta escuela ${ }^{3}$. La realidad de dependencia y pobreza que ha cargado América Latina, y que se refleja en la violación estructural de derechos humanos, ha sido, para la teología de la liberación, desde sus inicios hasta el día de hoy, el punto de partida para su elaboración. Esto la constataba Ellacuría de la siguiente manera, en referencia con la teoría que en la segunda mitad del siglo pasado cuestionó a la fe cristiana en Latinoamérica: "De hecho, la presencia de la teoría de la dependencia obliga a la teología a plantearse dos tareas fundamentales: una, la de repensar críticamente cuántas de las formulaciones teológicas y de las prácticas cristianas son dependientes, sin

3. Se puede considerar que la Teología de la Liberación tiene, en términos generales, cuatro etapas: (a) Génesis (1969-1971); (b) Crecimiento (1972-1979); (c) Consolidación (1979-1987); (d) Nuevos retos (1989-hoy día). Cf. R. Oliveros Maqueo, "Historia breve de la Teología de la Liberación (1962-1990)”, en I. Ellacuría y J. Sobrino (eds.), Mysterium liberationis, tomo I, UCA Editores, San Salvador, 1993, pp. 17-50. 
saberlo, de estructuras económicas, cuyo fruto último no puede ser otro que el de la dominación; otra, la de replantear positivamente cómo deben concebirse la fe y la praxis cristianas en un momento histórico y en una situación estructural descrita por la teoría de la dependencia y, más allá de la teoría de la dependencia, por la cruda realidad"4.

Ellacuría participó de manera importante en la consolidación de la teología de la liberación. Fue, sin duda, uno de los pensadores de la liberación que mejor fundamentación filosófica otorgó a sus posturas teológicas. En este sentido, es importante destacar que su preocupación por los derechos humanos no solo tenía fundamentos filosóficos y políticos, sino también teológicos; en otras palabras, su praxis por derechos humanos era también una praxis eclesial, una praxis realizada desde su fe cristiana y, por lo tanto, fundamentada teológicamente, aunque no haya realizado un reflexión teológica sobre derechos humanos de manera explícita. De ahí que sea legítimo realizar una lectura desde la sensibilidad de derechos humanos de algunos de sus conceptos teológicos.

\section{El sentido de la teología de Ellacuría}

La teología de Ellacuría se puede definir, por su sentido, como una reflexión de la praxis que busca hacer presente el reinado de Dios en la historia. De ahí que si su filosofía primera tiene como objeto la realidad histórica ${ }^{5}$, su pensamiento teológico conforma una teología histórica, es decir, un esfuerzo de historizar los principales conceptos teológicos de la fe cristiana para constituirse en un momento de la praxis cristiana, que pretende ser, a su vez, parte de la praxis de liberación. La realidad histórica no solo es un concepto filosófico, sino también teológico, pues lo que intenta Ellacuría es leerla y conceptualizarla teológicamente.

La teología de Ellacuría supera las elaboraciones neoescolásticas a través de una teología posidealista que busca responder a los desafíos de opresión e injusticia que marcan la realidad latinoamericana. Es decir, como señala Gustavo Gutiérrez, la pregunta central de la teología de la liberación es cómo hablar de Dios en un mundo de sufrimiento y de injusticia, a diferencia de la teología primermundista que se enfrenta al problema de hablar de Dios en un mundo moderno, fruto de la Ilustración y del conocimiento científico ${ }^{6}$. Por eso, la liberación "se constituye como principio unificador de los distintos temas teológicos.

4. I. Ellacuría, "Teorías económicas y relación entre cristianismo y socialismo", en Escritos teológicos, tomo I, UCA Editores, San Salvador, 2000, pp. 310-311.

5. Cf. I. Ellacuría, Filosofía de la realidad histórica, UCA Editores, San Salvador, 1999.

6. A partir de aquí, cuando hagamos referencia a la teología de la liberación se estará haciendo referencia a la perspectiva que de ella tuvo Ellacuría. 
Justicia y libertad, como procesos activos e históricos, se constituyen en pilares de la nueva teología. En la unión de la justicia (justificación) con la libertad (liberación) se logra una orientación a la par cristiana y secular, que permite señalar la transcendencia de lo histórico, donde transcender no significa un salirse de, sino un ahondar y totalizar. Justicia-libertad no es uno de los temas, sino la clave de interpretación"7. En efecto, desde esta perspectiva es como se puede asumir teológicamente a los procesos de derechos humanos, al ser considerados como parte de esa clave de interpretación "justicia-libertad".

Para Ellacuría donde con mayor plenitud se da la realidad es en la realidad histórica, pero a diferencia de la teología tradicional no concibe la existencia de dos historias. No se puede aceptar una historia del hombre y otra de Dios; no hay dos historias, sino solo una. Más bien, en la historia hay situaciones de gracia y hay situaciones de pecado; de justicia y de injusticia; de vida y de muerte. De ahí que la teología deba plantear con rigor y en términos históricos, el mensaje cristiano y los mejores anhelos de la humanidad, en busca de la transformación de una situación dominada por el pecado. De esta importancia por la historia proviene una de las diferencias más marcadas entre la teología de la liberación y la teología tradicional: "La oposición de la teología latinoamericana a la teología usual es fundamentalmente por la ahistoricidad de esta última y por su inefectividad para contribuir a la acción salvífica, históricamente considerada. La objeción fundamental contra ella no es que no haya surgido en América Latina, sino que no ha surgido de cara a la realidad histórica de las mayorías populares, ni siquiera en los países en que ha surgido" ${ }^{8}$. Nos encontramos con la necesidad de un logos histórico que supere las concepciones teológicas naturalistas propias del logos contemplativo, y de igual forma supere el logos puramente transformativo: "[E]l logos de la predicación y de la acción cristianas es también el logos histórico, un logos que tiene que ver con la historia y su transformación, pero también con el entendimiento de esa historia y con la iluminación de esa transformación".

Para la teología de la liberación, el discurso teológico es un momento segundo de la praxis. Esta teología nace para responder a preguntas nacidas del presente y del compromiso humano por cambiar las estructuras injustas; no se queda simplemente en "pensar el mundo", ni en la verdad de la fe cristiana o en su sentido, sino que parte de la realidad, pues pretende contribuir a la praxis por la liberación. Esta reflexión crítica se dirige a la realidad histórica, en cuanto que las estructuras que la forman se oponen a la realización del reinado de Dios; y a sí misma para evitar un estancamiento que la lleve a dogmatismos e ideolo-

7. I. Ellacuría, "Tesis sobre posibilidad, necesidad y sentido de una teología latinoamericana", en Escritos teológicos, tomo I, óp. cit., p. 280.

8. Ibíd., p. 277.

9. Ibíd., p. 295. 
gizaciones que no constituyan un auténtico discernimiento relativo a la praxis. Es decir, para Ellacuría, la teología como ejercicio racional carga con todas las características que son propias del uso de la inteligencia.

En otras palabras, la teología es el momento intelectivo o ideológico de la praxis eclesial ${ }^{10} \mathrm{y}$, por lo tanto, es una ideología con riesgos de convertirse en ideologización. Para no soslayar esta situación, y ser capaces de constatar la complejidad del problema, se debe encuadrar el quehacer teológico en la praxis eclesial y a ésta en la praxis histórica ${ }^{11}$, pues viendo a la teología como momento de una praxis determinada es más sencillo acercarse a su función propia. En efecto, la teología representa, de modo especial, el momento ideológico de la praxis eclesial, es decir, su momento consciente y reflejo: "Que la praxis eclesial sea un momento de una praxis histórica totalizante hace que esté determinada por el lugar que adopte en esa praxis histórica total. Porque la realidad nos muestra que la praxis histórica es una praxis dividida y conflictiva, de modo que esa es su forma actual de totalidad, con lo cual, según sea la posición adoptada en el conflicto, así será, en buena parte, su determinación propia"12.

De ahí que la teología de la liberación hunda sus raíces en la experiencia, en la praxis y en el compromiso de los seres humanos, y en especial de los cristianos, por la liberación. Comprende una hermenéutica real e histórica "porque lo que se trata de medir críticamente no es cuál es un determinado sentido teórico, sino cómo ha podido surgir realmente un determinado sentido a partir de un desde dónde físico"13. No obstante, la teología puede ser una ideologización que encubra lo que de falso e injusto tengan las estructuras sociales y las relaciones humanas; para evitar esto, Ellacuría considera necesario determinar el lugar teológico. Por éste entiende ${ }^{14}$ (a) El lugar donde el Dios de Jesús se manifiesta de modo especial, tanto como revelación como llamada a la conversión. (b) El lugar más apto para la vivencia de la fe en Jesús y para la correspondiente praxis de seguimiento. (c) El lugar más propio para hacer la reflexión sobre la fe, es decir, para realizar una teología cristiana.

Para la teología de la liberación es fundamental determinar el lugar social y la perspectiva desde los cuales generará su reflexión; si la teología es histórica, debe

10. Cf. I. Ellacuría, "La teología como momento ideológico de la praxis eclesial", en Escritos teológicos, tomo I, óp. cit., pp. 163-185.

11. Es importante tener en cuenta, para no desprestigiar el contenido de la teología de la liberación, que Ellacuría considera que la praxis eclesial es un momento de la praxis histórica totalizante, pero que mantiene cierta autonomía (cf. ibíd., p. 169).

12. Ibíd., pp. 171-172.

13. I. Ellacuría, "Hacia una fundamentación del método teológico latinoamericano", en Escritos teológicos, tomo I, óp. cit., p. 216.

14. Cf. I. Ellacuría, "Los pobres, 'lugar teológico' en América Latina”, en Escritos teológicos, tomo I, óp. cit., pp. 149-151. 
historizarse críticamente. Es decir, se pregunta si la fe cristiana se ve influida en la manera de interpretar la realidad social y si existe una forma específicamente cristiana de mirar la sociedad; a lo que se responde de manera afirmativa: desde los pobres. Pero estos no son solo los destinatarios de la teología de la liberación, sino su punto de partida. No se trata de una teología paternalista, sino de una teología puesta en movimiento desde el pobre como interlocutor y sujeto histórico. En este sentido, los pobres son el "lugar teológico privilegiado" ${ }^{5}$. Esta parcialidad no significa que la teología de la liberación renuncie a la universalidad de su reflexión; al contrario, posiciones consideradas universales que no pasen por un lugar social concreto terminan irremediablemente en la abstracción, en la ahistoricidad. En este sentido, Tamayo afirma que "[1]a fuerza universal de la teología de la liberación radica en su vinculación con el proyecto histórico de los oprimidos, en la asunción de las causas universales de la justicia, la vida, de la libertad, de la dignidad, que han de concretarse históricamente en la defensa de los derechos humanos de quienes se ven privados de ellos. Pues esos derechos sólo serán de verdad universales, cuando puedan disfrutar de ellos, sin cortapisa alguna, todos los hombres y todas las mujeres de nuestro planeta"16. En el mismo sentido, Ellacuría afirma que la teología de la liberación recupera "el universalismo histórico al romper la limitación occidental y al actualizar posibilidades inéditas de la fe" ${ }^{\prime 17}$. Teológicamente, el lugar-que-da-verdad como lugar epistemológico para hacerse cargo de la realidad histórica son los pobres, no solo por sus características como mayorías populares, sino también por su importancia en la fe cristiana, tanto por su presencia en la historia de la salvación en el Antiguo y Nuevo Testamento, como por ser signo de revelación de Dios en la historia.

Pero no basta establecer el lugar teológico para que la teología realmente colabore con la praxis de liberación. Ellacuría insiste en la necesidad de evitar las lecturas de la fe que conduzcan al moralismo ingenuo, al fundamentalismo y simplismo mesiánico, o al politicismo. Plantea más bien una actitud de "realismo creyente" que "supone y representa una actitud equilibrada, que tiene en cuenta tanto lo positivo del aporte evangélico para la propia acción política como los límites de ese aporte, precisamente por la relatividad específica y la autonomía de los dos ámbitos; tiene también en cuenta tanto lo positivo de la acción política para la realización del reino de Dios como los límites que le son propios"18. Para lograr este equilibro, destaca, entre otros factores, el uso de las ciencias sociales

15. Cf. S. Mier, El sujeto social en moral fundamental, UPM, México, 1996, pp. 177-179.

16. J. J. Tamayo-Acosta, Para comprender la teología de la liberación, Verbo Divino, Estella, 1998, p. 69.

17. I. Ellacuría, "El desafío cristiano de la teología de la liberación", en Escritos teológicos, tomo I, óp. cit., p. 32.

18. I. Ellacuría, "Teología de la liberación frente al cambio socio-histórico en América Latina", en Escritos teológicos, tomo I, óp. cit., p. 320. 
y humanas como mediaciones, pero sin absolutizarlas ni olvidar la autonomía de la fe y praxis cristianas: "Son necesarias tanto mediaciones teóricas como mediaciones práxicas para interpretar y transformar el mundo cristianamente"19. Además, la conexión entre la teología y las ciencias sociales tiene su razón en la unidad de la realidad histórica y del cuerpo social, a la cual ambas se dirigen.

\section{Derechos humanos e historización de la fe cristiana}

Hemos destacado la importancia de la historia y de la praxis en la teología de Ellacuría en relación con la construcción del reino de Dios. Es decir, el objeto fundamental de la teología sería ese reinado como realidad y concepto estructural histórico ${ }^{20}$. Pero la teología no puede reducirse a ser una interpretación de lo que es el reinado de Dios, sino que también debe de orientar hacia su realización histórica, sin llegar a confundirlo con un proyecto económico y político concreto. Pero para esto, el quehacer teológico no puede quedarse ajeno a la experiencia histórica ni al margen de las ciencias sociales: “...si la teología ha de orientar una realización histórica del reino de Dios, no podrá desempeñar su misión sin contar con lo que es en cada momento la praxis histórica y lo que son las condiciones reales para una recta incardinación de su esfuerzo en esa praxis histórica. El problema se presenta no sólo respecto de las acciones estratégicas y tácticas que han de emprenderse para que el curso histórico de los acontecimientos humanos quede más conformado por lo que es la exigencia del reino, sino respecto del reino de Dios mismo como concreción histórica"21. Entendiendo así la teología, como una reflexión sobre la praxis, incluso sobre la praxis histórica total y no meramente sobre la praxis eclesial, que busca la realización del reinado de Dios en la historia, es como los derechos humanos pueden ser parte de su reflexión, tanto como mediación práctica como teórica. La praxis de la fe cristiana en América Latina ha mostrado que la lucha por y la reflexión sobre derechos humanos son mediaciones que la teología de la liberación debe tomar en cuenta. Esto sin olvidar que, en la teología de la liberación, "la cuestión social ya no se reduce a la cuestión de la justicia social clásica, sino que es la cuestión de la realización plena del hombre y de la historia, el problema de la salvación histórica como lugar de la revelación y de la realización de lo absoluto"22.

19. I. Ellacuría, "Hacia una fundamentación del método teológico latinoamericano", óp. cit., p. 216.

20. Cf. I. Ellacuría, "La teología como momento ideológico de la praxis eclesial", óp. cit., p. 177.

21. Ibíd., p. 179.

22. I. Ellacuría, "Tesis sobre posibilidad, necesidad y sentido de una teología latinoamericana”, óp. cit., p. 289. 
Tomando en cuenta lo anterior, analizaremos algunos conceptos teológicos que nos otorgan bases para iluminar la reflexión sobre derechos humanos desde la fe cristiana. Cabe aclarar que nuestro autor no realizó reflexiones teológicas explícitas sobre derechos humanos, aunque en muchas de sus posturas teológicas hay una proximidad muy grande con su postura político-filosófica al respecto.

\subsection{El pueblo crucificado: injusticia y pecado}

"Pueblo crucificado" es uno de los conceptos más destacados de la teología de Ellacuría, pues a través de él realiza la historización de una parte de la fe cristiana. Por un lado, toma un concepto político, el de "pueblo", que es importante en relación al sujeto y destinatario de las luchas de liberación en América Latina; y, por otro lado, asume el concepto de "crucifixión", de "cruz", de "el crucificado", que ha tenido un significado importante en la teología cristiana. Pero, sobre todo, es un concepto que parte de un análisis de la situación de la realidad histórica, donde se verifica la existencia de mayorías populares en situación de pobreza, de explotación y de exclusión ${ }^{23}$. Ellacuría constata una realidad donde gran parte de la humanidad está "literal e históricamente crucificada por opresiones naturales y, sobre todo, por opresiones históricas y personales"24. Pero la crucifixión del pueblo no está relacionada directamente con las opresiones naturales, sino con las históricas y personales; si la crucifixión de Jesús fue realizada por seres humanos, tanto por individuos como por sus estructuras de dominación, de la misma manera es como se crucifica actualmente al pueblo. Es decir, pueblo crucificado es "aquella colectividad que, siendo la mayoría de la humanidad, debe su situación de crucifixión a un ordenamiento social promovido y sostenido por una minoría que ejerce su dominio en función de un conjunto de factores, los cuales, como tal conjunto y dada su concreta efectividad histórica deben estimarse como pecado" 25 .

A diferencia de la teología tradicional, la reflexión sobre "la cruz" no se trata de una consideración individual e intimista. Se trata, en cambio, de una crucifixión colectiva, de todo un pueblo, que sin negar su individualización, es consecuencia de una cuestión colectiva y estructural. Situación que niega a la mayoría de la humanidad la satisfacción de sus necesidades y, por lo tanto, del disfrute de derechos humanos. Una realidad marcada por la muerte, pero no por cualquier tipo de muerte, sino por aquélla que es infligida de manera directa

23. Este concepto es desarrollado por Ellacuría principalmente en un artículo publicado por primera vez en 1978 (AA. VV., Cruz y resurrección, CRT, México, 1978, pp. 49-82). Recogido también en el tomo II de Misterium liberationis, óp. cit., y en el tomo II de los Escritos teológicos. Aquí citaremos esta última edición.

24. I. Ellacuría, "El pueblo crucificado. Ensayo de soteriología histórica", en Escritos teológicos, tomo II, UCA Editores, San Salvador, 2000, p. 137.

25. Ibíd., pp. 152-153. 
por estructuras injustas. Como señala Jon Sobrino, morir crucificado significa ser dado a muerte, y no simplemente morir ${ }^{26}$. Así, el "pueblo crucificado" es un signo que expresa una negatividad específica, y que caracteriza centralmente la realidad actual ${ }^{27}$. Si no se toma en cuenta este signo, se está realizando un abordaje parcial de la realidad y, por lo tanto, es imposible "hacerse cargo" de ella.

Ellacuría realiza una lectura sobre el texto del Siervo de Yahvé (Is 52, 13-53, 12) relacionándola con la muerte de Jesús y con el pueblo crucificado $^{28}$. Se basa en un presupuesto: el encuentro de Yahvé ocurre en la historia. La unidad de la historia significa, en este caso, que Yahvé ha salido al encuentro de su pueblo, y muestra cuáles deben ser las características para que el pueblo sea continuador de la obra de Jesús. Este texto se compone de cuatro cánticos. En el primero se habla del Siervo de Yahvé como un elegido de Dios con el fin de que "traiga el derecho a las naciones"; una implantación de la justicia y del derecho en el sentido más importante dentro de la tradición bíblica: hacer justicia al oprimido. El segundo cántico se refiere al carácter de la elección: Dios ha elegido a quien es despreciado por los poderosos, a quien parecería que no tiene la fuerza suficiente para realizar la justicia en el mundo. El tercer cántico resalta la importancia que tienen los sufrimientos en la marcha del pueblo hacia su liberación. Por último, el cuarto cántico es el central en cuanto a la lectura que realiza Ellacuría, pues versa sobre la pasión y la gloria del Siervo. En él, destaca algunos momentos histórico-teológicos que se relacionan con el pueblo crucificado, tanto por la forma y causas de su sufrimiento como por su función salvadora.

Ellacuría sostiene que no se puede determinar unívocamente la concreción histórica del Siervo. En cierto sentido, todo aquel que realice la misión descrita en este texto bíblico será Siervo de Yahvé, es decir, "será todo aquel crucificado injustamente por los pecados de los hombres, porque todos los crucificados forman una sola unidad, una sola realidad, aunque esta realidad tenga cabeza y tenga miembros con funciones distintas en la unidad de la expiación" 29 . Lo que busca es mostrar que el pueblo crucificado cuenta de forma objetiva con algunas de las condiciones esenciales del Siervo de Yahvé para así asumirlo como el lugar histórico más adecuado para su realización, aunque actualmente no lo sea en toda su plenitud. De ahí que se debe asumir que la continuación histórica de la pasión de Jesús puede adoptar diversas figuras. En efecto, siempre será el "pueblo de Dios crucificado", pero este concepto debe ser historizado, tomando su "semejanza" con lo ocurrido al Jesús crucificado en la historia: “...deberá ser

26. $C f$., también sobre el "pueblo crucificado", J. Sobrino, Jesucristo liberador, CRT-UIA, México, 1994, pp. 313-333.

27. Cf. J. Sobrino, Fuera de los pobres no hay salvación, Trotta, Madrid, 2007, pp. 20-21.

28. $C f$. I. Ellacuría, "El pueblo crucificado. Ensayo de soteriología histórica", óp. cit., pp. 156-170.

29. Ibíd., p. 163. 
crucificado por los pecados del mundo, deberá haber sido convertido en desecho de los hombres mundanos, su apariencia no será humana, precisamente porque ha sido deshumanizada; deberá tener un alto grado de universalidad, pues se ha de tratar de una figura redentora del mundo entero; deberá sufrir esa deshumanización total, no por sus culpas, sino por cargar con las culpas de los demás; deberá ser desechado y despreciado, precisamente como salvador..." ${ }^{30}$.

Si el pueblo es crucificado por el pecado, ¿cómo comprende Ellacuría este concepto teológico? En síntesis, podemos afirmar que realiza una conexión entre el concepto filosófico-político de "injusticia" con el concepto teológico de "pecado". Sumándose a una postura común entre los teólogos de la liberación, el pecado no sólo se queda en el ámbito intimista e individual, sino que también se expresa en las estructuras sociales, y se relaciona de manera directa con la violencia estructural. Siempre es cometido por personas, pues los animales, la naturaleza o las estructuras no pecan, pero esto no significa encerrarlo en el ámbito de lo privado, de lo subjetivo y voluntarista. El "pecado social" es la expresión teológica del "mal común", y es el que conduce a su crucifixión al pueblo, el que lo mantiene en una situación análoga a la del Siervo de Yahvé.

La injusticia es la objetivación del pecado; por eso, Ellacuría señala que el Tercer Mundo "no es sólo el lugar histórico de la objetivación de la dominación: es también el lugar teológico de la objetivación del pecado"31. Esta objetivación se realiza a través de estructuras sociopolíticas y económicas propias de la "civilización de la riqueza" ${ }^{32}$ y de las relaciones de opresión entre el Norte y el Sur. Una situación que se considera de "pecado" porque es contraria al plan previsto por Dios; de ahí que Ellacuría considere que el juicio cristiano de la situación imperante en Latinoamérica debe estar encabezado por la categoría de pecado ${ }^{33}$. Las estructuras, insistimos, no pecan, pues carecen de libertad personal, pero se debe tener en cuenta que "el mal del mundo, el pecado del mundo no es sin más la suma de determinadas acciones individuales, ni éstas son ajenas a ese pecado que las domina" ${ }^{34}$. Más bien, el pecado social es la estructuración del pecado del ser humano, consecuencia de pecados personales e individuales. Estas estructuras son la mayor manifestación del poder del pecado, y dificultan que los seres humanos puedan construir su vida según el reinado de Dios. Son una realidad colectiva que fundamenta y posibilita los pecados individuales. Son estructuras violentas y, además de ser la violencia más grave, se constituyen como la raíz

30. Ibíd., p. 167.

31. I. Ellacuría, "Teorías económicas y relación entre cristianismo y socialismo”, óp. cit., p. 309.

32. I. Ellacuría, "Utopía y profetismo", en Mysterium liberationis, óp. cit.

33. Cf. I. Ellacuría, "Liberación: misión y carisma de la Iglesia latinoamericana", en Escritos teológicos, tomo II, óp. cit., pp. 571-584.

34. I. Ellacuría, "El pueblo crucificado. Ensayo de soteriología histórica”, óp. cit., p. 148. 
de toda violencia, pues mantienen "a la inmensa mayoría de la humanidad en condiciones biológicas, culturales, sociales y políticas absolutamente inhumanas. Esa es la violencia estructural fundamental" 35 .

Esta caracterización de la realidad de las mayorías populares como pueblo crucificado por el pecado social y por la violencia estructural, permite ubicar los derechos humanos en el ámbito teológico. Lo que padece el pueblo crucificado puede comprenderse como la negación de su humanidad, de la satisfacción de sus necesidades, y como impedimento a la reproducción de su vida. Es decir, como una situación donde se niegan derechos humanos. En este sentido, para Ellacuría la muerte y la opresión causadas por la civilización de la riqueza no son solo cuestiones morales, políticas o económicas, sino también teológicas: "La destrucción de la naturaleza no es sólo un problema ecológico, que pone en peligro la vida y la calidad de la vida, sino que es un problema teológico, en el cual se manifiesta la pecaminosidad del hombre y se oculta la gloria de Dios. La destrucción de la vida humana o su empobrecimiento no es ni tan siquiera un problema puramente moral, sino que es también, y sin fisuras o diferenciaciones, un problema teológico, el problema del pecado puesto en acción y el problema de la vida divina negada en la existencia humana" ${ }^{36}$. Y en otro texto, Ellacuría expresa esta negatividad de la historia en términos jurídico-políticos: “Cuándo unas estructuras son evidentemente injustas? ¿Cuándo esas estructuras representan la institucionalización de la violencia? La respuesta es clara: cuando atentan gravemente contra los derechos fundamentales de la persona y cuando dañan peligrosamente el bien común del país. Quiere esto decir que, cuando la situación estructural de un país, el conjunto de su organización económica, de su organización jurídica y de su organización política, llevan durante un tiempo prolongado a la negación de los derechos fundamentales de la persona, tales como el derecho a la vida, el derecho a la alimentación y a la salud, el derecho a la educación, el derecho a la libertad, el derecho a un juicio justo, el derecho a no ser apresado injustamente y a no ser torturado, el derecho a la organización política, el derecho a la libre expresión, etc., entonces estamos ante estructuras evidentemente injustas y ante la violencia institucionalizada" ${ }^{37}$.

Además de la negatividad del sufrimiento como consecuencia del pecado, la reflexión sobre el pueblo crucificado tiene una dimensión positiva. Ésta se relaciona con el "Siervo de Yahvé", el cual, a pesar de ser despreciado, traerá la

35. I. Ellacuría, "Quinto centenario de América Latina, ¿descubrimiento o encubrimiento?", en Escritos teológicos, tomo II, óp. cit., p. 536.

36. I. Ellacuría, "Aporte de la teología de la liberación a las religiones abrahámicas en la superación del individualismo y del positivismo", en Escritos teológicos, tomo II, óp. cit., pp. 204-205.

37. I. Ellacuría, "Comentarios a la Carta Pastoral", en Escritos políticos, tomo II, UCA Editores, San Salvador, 1993, p. 725. Cursivas mías. 
salvación al mundo. Se trata del desarrollo de una "soteriología histórica" que afirma que el sufrimiento y la muerte del pueblo crucificado traen salvación. Una salvación cuya versión historificada es la liberación ${ }^{38}$.

\subsection{El pueblo de Dios: salvación y liberación}

La teología de Ellacuría afirma insistentemente que la historia de la salvación no es tal si no alcanza a influir en la dimensión sociopolítica, que aunque no sea su totalidad es una de sus partes esenciales. La historicidad de la salvación cristiana, en su necesidad de acomodarse, encarnarse e historizarse en la realidad de América Latina y de otros países del Sur, se presenta como liberación. Por eso, Ellacuría critica la deshistorificación de la salvación que ha realizado la teología tradicional, que formula los grandes temas de la fe cristiana dentro del marco conceptual de la filosofía griega. Y esto lo plantea desde una cuestión básica: "Qué tiene que ver la historia de la salvación con la salvación de la historia"39.

La teología de la liberación pretende un cambio no solo en las personas, sino también en las estructuras sociohistóricas; Ellacuría nombra e interpreta este cambio en términos de liberación. Una liberación que teológicamente se puede expresar, siguiendo a Pablo de Tarso, como una liberación del pecado, de la ley y de la muerte, lo que, en términos históricos, significa la liberación de todo aquello que oprime al ser humano y le impide gozar de su vocación de hijo de Dios. Se trata de una liberación integral: "La teología de la liberación busca estructuras y comportamientos más justos y libres. Aunque la fe cristiana no es suficiente por sí misma para la liberación $-\mathrm{y}$, en ese sentido, no volvemos a caer en autocracias, ni en cristiandades, ni en nada semejante-, sí entendemos que la fe puede ser un aporte fundamental para la liberación integral de las personas, sin dualismo ninguno. Es obvio que por mucho que prediquemos y por mucho que procesionemos, y por mucho que celebremos, no vamos a arreglar, sólo con la fe, la historia. Hace falta técnica, hacen falta políticos, hacen falta muchas cosas. La liberación integral no puede hacerse al margen de procesos de desarrollo y de cambios políticos, más o menos revolucionarios. Pero el aporte de la fe $-\mathrm{y}$ esto no lo hemos sacado de otras teorías, sino de nuestra experiencia en América Latina - indica valores, direcciones, actitudes, etc., que, en cada caso, necesitan cierta traslación. Por lo tanto, la historia tiene ese carácter de salvación. La salvación la entendemos como liberación. Como liberación integral en nuestra situación”"40.

38. Cf. J. J. Tamayo-Acosta, "El método de historización de los conceptos teológicos en Ellacuría”, en J. A. Nicolás y H. Samour, Historia, ética y ciencia. El impulso crítico de la filosofía de Zubiri, Editorial Comares, Granada, 2007.

39. I. Ellacuría, "Historia de la salvación y salvación en la historia", en Escritos teológicos, tomo I, óp. cit., p. 520.

40. I. Ellacuría, "El desafío cristiano de la teología de la liberación”, óp. cit., p. 25. 
Uno de los ejemplos de la relación entre la historia de la salvación y la salvación de la historia está en el Antiguo Testamento. Ellacuría se suma a los autores de la teología de la liberación que realizan una lectura del Éxodo y de la Alianza entre el pueblo de Israel y Yahvé en términos históricos, es decir, dentro del marco de la relación salvación-liberación; como una experiencia que continúa durante todo el Antiguo Testamento y llega a su expresión cristiana con el Reino de Dios y el seguimiento de Jesús de Nazaret ${ }^{41}$. Una liberación que está ligada de manera estrecha con el concepto teológico del "Pueblo de Dios" —que, a su vez, nos remite al "pueblo crucificado"- y que hace hincapié en que si el "sujeto de la libertad puede ser individual, el sujeto de la liberación es, de una u otra forma, la colectividad, el pueblo"42. La relación de Dios y su pueblo, como lo ve Ellacuría tanto en el Nuevo como en el Antiguo Testamento, se logra a través de la mediación histórica, la cual en última instancia tiene que ver con la opresión y la dominación de un pueblo en busca de su liberación y que lucha históricamente por constituirse en pueblo libre ${ }^{43}$.

La liberación es un proceso colectivo; si bien el beneficiario último es el individuo, éste lo es dentro de la pertenencia a un pueblo. Por eso Ellacuría, desde su teología, critica las posturas tanto individualistas como colectivistas del ser humano, y otorga fundamental importancia al concepto "Pueblo de Dios". La teología de la liberación busca recuperar el sentido de este concepto, donde "pueblo" se entiende fundamentalmente como el pueblo de los pobres por opresión: es preferencialmente un pueblo de pobres, constituido a favor de los pobres, y cuya opción preferencial es la liberación de los pobres. Sin negar la dimensión individual de la salvación, se debe comprender que la salvación ofrecida históricamente por Dios ha sido a un pueblo: "No se puede negar que el cristianismo, como cultura, ha llevado el problema de la humanización y de la salvación por el camino de la individualización personal y de la interiorización; es una dimensión de la modernidad que no puede ser despreciada y que es fomentada por el mensaje bíblico del Antiguo y del Nuevo Testamento. Pero aun siendo esto verdad, hay que mantener que la salvación es ofrecida por Dios a un pueblo y para que se constituya un pueblo, entre otras razones, porque el camino del individualismo y de la subjetividad exagerados lleva a la negación del sentido comunitario y difusivo del Dios trino" ${ }^{44}$.

41. Cf. C. Bravo, "Del tema del Éxodo al seguimiento de Jesús", en J. Comblin, J. I. González Faus y J. Sobrino (eds.), Cambio social y pensamiento cristiano en América Latina, Trotta, Madrid, 1993, pp. 79-100.

42. I. Ellacuría, "Aporte de la teología de la liberación a las religiones abrahámicas en la superación del individualismo y del positivismo", óp. cit., p. 217.

43. $C f$. I. Ellacuría, "Iglesia como pueblo de Dios", en Escritos teológicos, tomo II, óp. cit., p. 320.

44. Ibíd., p. 326. 
El verdadero pueblo de Dios debe ser realmente un pueblo y no meramente un individuo. En la realidad histórica actual, en concreto desde América Latina, para Ellacuría son cuatro las características para que el pueblo de Dios vaya constituyéndose en verdadero pueblo de Dios: (a) la opción preferencial por los pobres; (b) la encarnación histórica en las luchas del pueblo por la justicia y la liberación; (c) la introducción de la levadura cristiana en las luchas por la justicia; y (d) la persecución por causa del reino de Dios en la lucha por la justicia ${ }^{45}$. Es decir, si una realidad marcada por la injusticia y la violencia estructural es caracterizada como una situación de pecado, el pueblo de Dios se debe encontrar en un proceso de liberación de este pecado. Por eso señala Ellacuría que cada individuo que compone el pueblo de Dios debe practicar la justicia "en el amplio sentido que esta práctica tiene en el mensaje revelado"46. ¿Cuál es este amplio sentido de la justicia?

Ellacuría analiza el tema de la relación entre la fe y la justicia en un largo $\operatorname{artículo}^{47}$. Su objetivo es mostrar un modelo crítico para enfrentar cristianamente los problemas históricos, al considerar que se debe superar la falsa contraposición entre la fe y la justicia. Considera, pues, que a la fe le pertenece integralmente la justicia, pues no tiene fe cristiana total quien no realiza obras de justicia. Esta afirmación la fundamenta en una profunda convicción cristiana: la prioridad del amor. La justicia se entiende como una forma de amor, y entonces no hay "discusión posible sobre la prioridad real del amor sobre la fe y, por lo tanto, de la justicia, si se presenta como una forma histórica del amor"48. En efecto, justicia es una forma histórica que adopta el amor en un mundo de opresión y pecado.

Fe y justicia se hacen presentes en la historia de la salvación y en el proceso de liberación del pueblo de Dios. Nuestro autor destaca el peso del tema de la justicia en el Antiguo Testamento. La experiencia de liberación del primer Éxodo tiene un gran valor para la reflexión de derechos humanos, pues las leyes tuvieron un papel importante. Podemos decir que, en términos contemporáneos, el pueblo de Dios buscó la manera de positivizar en sus códigos y leyes la satisfacción de sus necesidades y el establecimiento de las condiciones para reproducir su vida.

En la realidad histórica, la experiencia de la injusticia es un hecho previo a la definición de justicia. Este binomio justicia e injusticia tiene una gran importancia en el Antiguo Testamento. Ese fue el camino que siguió el pueblo de Israel: primero experimentó la injusticia y la opresión, y a partir de esa expe-

45. Cf. I. Ellacuría, "Aporte de la teología de la liberación a las religiones abrahámicas en la superación del individualismo y del positivismo", óp. cit., p. 209.

46. I. Ellacuría, "Iglesia como pueblo de Dios", óp. cit., p. 329.

47. I. Ellacuría, "Fe y justicia", en Escritos teológicos, tomo III, UCA Editores, San Salvador, 2002, pp. 307-373.

48. Ibíd., p. 315. 
riencia, fue elaborando un proyecto donde la justicia imperara en las relaciones humanas. Este proyecto de construir una sociedad justa fue comprendido por los pobladores de Israel como el plan que Yahvé les proponía y por el cual realizaron una "Alianza" con él ${ }^{49}$. Un proyecto histórico que superaba las visiones naturalistas de Dios y que surgió de la experiencia de opresión, pues respondía a los gritos que lanzaban y a las necesidades que tenían los hebreos cuando eran esclavos en Egipto o eran explotados por el sistema cananeo. Este es el sentido de Éxodo 3, 7-8: "Yahvé dijo: 'He visto la humillación de mi pueblo en Egipto, y he escuchado sus gritos cuando lo maltrataban sus mayordomos. Yo conozco sus sufrimientos. He bajado para librarlo del poder de los egipcios y para hacerlo subir de aquí a un país grande y fértil, a una tierra que mana leche y miel"'. Las características de este proyecto de liberación pretendieron ir contra algún aspecto de la organización del Imperio egipcio o de los reinos cananeos ${ }^{50}$.

Este proyecto no solo se encontraba en las buenas intenciones del pueblo. $\mathrm{Si}$ actualmente se tienen noticias de él es gracias a que quedó asentado en las leyes, pues las tribus de Israel experimentaron la utilidad del derecho para la organización social. En este sentido, por ejemplo, encontramos el desarrollo de una legislación social que buscaba combatir la pobreza a través de la justa distribución de la riqueza. Algunas instituciones jurídicas que buscaban este fin fueron las siguientes: (a) el año sabático, el cual consistía en el perdón de las deudas cada siete años (Dt 15, 1-6). (b) La prohibición del préstamo con interés (Dt 23, 19-21). También se prohibía tomar en prenda objetos de primera necesidad (Dt 24, 6). (c) El año jubilar, el cual consistía en la recuperación de las tierras propias cada cincuenta años (Lv 25, 8-12). Esta ley del jubileo prohibía que los individuos acumularan grandes extensiones de tierra para provecho exclusivo. Restauraba el derecho de la persona a su tierra. Así, cada cincuenta años las desigualdades socioeconómicas terminaban y cada miembro de la sociedad podía empezar un nuevo ciclo de oportunidades. (d) El otorgar derechos a los huérfanos, las viudas y los extranjeros residentes para que dejaran de ser pobres (Dt 15, 11; 24, 19-22; 26, 12-13; Lv 19, 9-10). Lo cual refleja la actual posición del Derecho Social que tiene la intención de establecer desigualdades jurídicas para crear igualdad de hecho. (e) La sustitución de los tributos que otros pueblos pagaban a sus reyes por un impuesto destinado a los pobres (Dt 14, 28-29). Es decir, los tributos en función de su uso social y no para el mantenimiento de las cortes reales.

49. Una obra importante en el tema de la sociedad alternativa a partir del Éxodo, y que ha sido utilizada por algunos teólogos de la liberación, es N. K. Gottwald, The tribes of Yahweh. A sociology of the religion of liberated Israel, 1250-1050 BCE, Sheffield Academic Press, Sheffield, 1999. Una breve revisión sobre esta obra es N. K. Gottwald, "Revisiting The Tribes of Yahweh", Revista Electrónica Latinoamericana de Teología. Disponible en http://servicioskoinonia.org/relat/374e.htm.

50. Cf. J. L. Caravias et ál., Tu palabra me da vida, CRT, México, 1990, pp. 55-65. 
Se le puede considerar como el primer impuesto social conocido. Ciertamente, historiadores y exégetas discuten la puesta en práctica que tuvieron estas instituciones, en especial el año sabático y el año jubilar, pero lo importante es caer en la cuenta de que verdaderamente manifiestan con claridad la preocupación que tuvo la legislación por abolir la pobreza, entendiéndola como consecuencia de la acción de los hombres y como negación de la más elemental justicia.

Los ejemplos citados muestran la forma en que la ley estaba al servicio de una nueva sociedad, pues nacieron para impedir que se repitieran las injusticias que se cometían en Egipto. Por eso, estas leyes no intentaron proteger un "orden establecido", ni justificar situaciones profundamente injustas y opresoras dándoles el carácter de legales, ni mucho menos permitir el abuso del poder. La legislación solo se podía explicar a partir de la salida de Egipto, pues su auténtico sentido estaba en el rompimiento con la esclavitud, entendida ésta como la experiencia más radical de la injusticia (Dt 6, 20-25). Por eso, el sentido de las leyes del antiguo Israel se encuentra en el paso de la esclavitud en Egipto a la libertad; es decir, desde el proceso colectivo que constituye la liberación. No solo fue la experiencia fundante de la identidad de un pueblo, sino también de todo un derecho. Por eso, sus leyes eran justas no porque "le daban a cada quien lo suyo", sino porque contribuían con el proceso por el cual el oprimido recupera su condición de persona libre.

La experiencia del Éxodo y la organización del pueblo hebreo en sus primeros años muestran cómo la ley puede coadyuvar con la realización histórica de la justicia y en el proceso de liberación. Una ley nacida a espaldas del pueblo suele responder a intereses de unos cuantos, de los poderosos política y económicamente, y lejos estará de reivindicar en su dignidad a quienes les ha sido despojada. En cambio, una ley que nace como respuesta a los gritos y sufrimientos de los sectores sociales menos favorecidos estará en mayores posibilidades de servir como arma de liberación ${ }^{51}$. De ahí que, desde la experiencia del Éxodo, se pueda comprender la justicia y el derecho como parte de un proceso de liberación. Esta es la manera como entiende Ellacuría a la justicia, es decir, que cada uno sea, tenga y se le dé, no lo que se supone que ya es suyo porque lo posee, sino lo que le es debido por su condición de persona humana y de miembro de una determinada comunidad o sociedad ${ }^{52}$. Y esto es el sentido principal del derecho (mispât) en la Biblia: Salvar de la injusticia, de la opresión, y liberar al oprimido ${ }^{53}$.

51. $C f$. J. A. de la Torre Rangel, El derecho como arma de liberación en América Latina, UASLP-CEDH-CENJUS, San Luis Potosí, 2006.

52. Cf. I. Ellacuría, "En torno al concepto y a la idea de liberación", en Escritos teológicos, tomo I, óp. cit., pp. 629-657.

53. Cf. A. Rosillo Martínez, "El derecho en la tradición bíblica, un concepto análogo", en J. A. de la Torre Rangel (coord.), Hermenéutica analógica, derecho y derechos humanos, Universidad Autónoma de Aguascalientes, 2004, pp. 211-286. 


\subsection{El reinado de Dios}

La experiencia de liberación del Éxodo continúa en el Nuevo Testamento con la predicación del Reino de Dios por Jesús de Nazaret. Para Ellacuría, el objeto fundamental de la teología es el reino de Dios como realidad y concepto estructural histórico. Es un concepto dinámico, donde la reflexión teológica no solo está en función de encontrar su sentido, sino en orientar su realización en la realidad histórica, tomando en cuenta que ésta nunca será plena y siempre existirá una dimensión utópica ${ }^{54}$. El Reino de Dios asume la tradición liberadora del Antiguo Testamento y está relacionado directamente con la praxis y mensaje de Jesús de Nazaret. De ahí la importancia que en la teología de la liberación tiene la recuperación del Jesús histórico y de su dimensión política.

El mensaje de Jesús fue un mensaje político-religioso. Así lo entendieron sus contemporáneos, y seguramente esa fue su auténtica intención. Aquí, por político se entiende alguien que ejerce de manera abierta y explícita un sistema de medios sociopolíticos para ponerlos al servicio de una concepción determinada del sentido del ser humano y de su existencia social; en este sentido, Jesús de Nazaret ejerció una actividad política ${ }^{55}$. Veamos algunos pasajes de los Evangelios que son destacados por Ellacuría para recuperar dicha dimensión política.

Los Evangelios de Lucas y Mateo presentan uno de los textos más conocidos sobre Jesús: las bienaventuranzas o el sermón del monte. Ambos evangelistas realizaron un trabajo redaccional propio para presentar y adaptar las bienaventuranzas a las necesidades de sus comunidades. Más allá de la discusión sobre la historicidad de dicho discurso, es claro que presenta una síntesis del significado de la praxis y mensaje de Jesús; y este significado queda más claro en la reconstrucción de la fuente $\mathrm{Q}^{56}$. El mensaje contenido en las bienaventuranzas es de indudable contenido político. En ellas se expresa: "Felices los pobres..., felices lo que lloran..., felices los que tienen hambre...". Es muy frecuente escuchar interpretaciones moralizantes al respecto, donde se hace hincapié en la felicidad que se debe tener a pesar de que se sufra pobreza, dolor o hambre, ya que el consuelo final vendrá en el "reino de los cielos". Sin embargo, el sentido en Jesús es diferente. Los pobres, los que lloran y los que tienen hambre son felices porque, según el plan que Dios tiene para el ser humano, dejarán de ser pobres, serán consolados y tendrán con qué saciarse. Esto es así porque "Dios y su reino son

54. Cf. I. Ellacuría, "El verdadero pueblo de Dios, según monseñor Romero", en Escritos teológicos, tomo II, óp. cit., p. 374.

55. Cf. I. Ellacuría, "Carácter político de la misión de Jesús", en Escritos teológicos, tomo II, óp. cit., pp. 13-32; y "Dimensión política del mesianismo de Jesús", ibíd., pp. 34-66.

56. Cf. J. L. Segundo, El hombre de hoy ante Jesús de Nazaret, II/1, Ediciones Cristiandad, Madrid, 1982, pp. 156-177. 
parciales y activamente parciales" a favor de los pobres, como afirma Ellacuría al referirse a las bienaventuranzas en la versión de Lucas ${ }^{57}$.

La praxis de Jesús no fue neutra. Su concepción del sentido del ser humano se contrapuso totalmente con la concepción de muchos de sus contemporáneos. Los evangelistas muestran que las acciones de Jesús van encaminadas a favor de los pobres, de los sectores relegados socialmente y de quienes sufren algún tipo de opresión. Y estas acciones están sobre la base de la experiencia que Jesús tuvo de Dios: un padre bueno deseoso de justicia para todos los seres humanos, sus hijos. Dichas acciones fueron creándole enemigos a Jesús entre aquellos sectores que ejercían el poder, fuera este social, económico, político o religioso.

El conflicto de Jesús con los poderosos, consecuencia de su praxis y mensaje, lo llevó a la muerte. Ciertas teologías han presentado esta muerte como una inmolación con carácter expiatorio, como una entrega voluntaria sin más, como el cumplimiento de una exigencia de Dios a la persona de Jesús. Sin embargo, los Evangelios muestran que la muerte de Jesús tuvo un contenido políticoreligioso $^{58}$. La hostilidad en su contra por parte de diversos grupos de poder de la sociedad judía llegó al extremo de planear en conjunto su muerte. Como señala Ellacuría, lo que le ocurrió en la muerte a Jesús fue la consecuencia de lo que actuó en vida, pues la lucha "por el reino de Dios suponía, necesariamente, una lucha a favor del hombre oprimido de manera injusta. Esta lucha debía llevar, necesariamente, al enfrentamiento con los responsables de la opresión. Por eso murió" 59 .

En un artículo relacionado con la conversión de la Iglesia hacia el reino de Dios, Ellacuría enumera y explica cinco características de lo que éste es ${ }^{60}$ : (a) el anuncio de Jesús no es sobre sí mismo ni sobre la Iglesia, sino versa principalmente en el reino de Dios. (b) El reino no es un concepto espacial, ni estático, sino una realidad dinámica: no es un reino, sino un reinado, "una acción permanente" sobre la realidad histórica. (c) El reino es pauta para superar ciertos dualismos interesados, tales como inmanencia-transcendencia, horizontalidad-verticalidad, profano-sagrado, etc. En este sentido, no se puede separar a Dios de la historia, pues el reino es la presencia activa de aquél en la historia y la presencia de ésta en Dios. Se trata de la historización de Dios, algo tan escandaloso como la encarnación o la divinización de la historia. (d) El reino es un reino de los pobres, de

57. Cf. I. Ellacuría, "Las bienaventuranzas, carta fundacional de la Iglesia de los pobres", en Escritos teológicos, tomo II, óp. cit., pp. 417-439.

58. Cf. I. Ellacuría, “¿Por qué muere Jesús y por qué lo matan?”, en Escritos teológicos, tomo II, óp. cit., pp. 67-88.

59. Ibid., p. 87.

60. I. Ellacuría, "Recuperar el reino de Dios: desmundialización e historización de la Iglesia”, en Escritos teológicos, tomo II, óp. cit., pp. 313-316. 
los oprimidos y de los excluidos. Los protagonistas del reino son los que sufren injusticia y fundamentan su protagonismo en la presencia peculiar del reino en ellos. (e) El reino supera la dualidad entre lo personal y lo estructural, entre la ética personal y la ética social. No es una pura cuestión de fe, sino también de obras de justicia. Sobre estas características que enuncia Ellacuría haremos un acercamiento al reinado de Dios desde la sensibilidad de los derechos humanos.

En el Evangelio de Mateo se encuentra un texto que expresa con claridad el sentido de la praxis de Jesús. Cuando un grupo de discípulos de Juan el Bautista le pregunta si es "el que ha de venir", él responde: "Vayan y cuéntenle a Juan lo que han visto y oído: los ciegos ven, los cojos andan, los leprosos quedan sanos, los sordos oyen, los muertos resucitan, y una buena noticia ha llegado a los pobres" (Mt 11, 4-5). La construcción de una humanidad según Dios consiste en la superación de las actuales situaciones de injusticia y opresión, donde los que vivían en situaciones de muerte, vuelven a disfrutar de la abundancia de la vida. En este sentido, el reinado de Dios es la superación de todas esas situaciones y estructuras que deshumanizan al hombre; es la sociedad alternativa donde todos los pobres y oprimidos superan su pobreza y opresión para tener acceso a una vida digna y en abundancia. Por tanto, conlleva necesariamente la crítica de estas situaciones injustas $\mathrm{y}$, al mismo tiempo, infunde esperanzas al anunciar que la construcción de la historia no concluye mientras dichas situaciones no sean efectivamente abolidas, mientras la miseria de la propia historia no sea superada. El reinado de Dios no es sin más otro mundo, sino este mismo mundo pero totalmente otro. De ahí que su construcción se da por el sendero de la transformación histórica, y sea necesaria una constante historización: "La riqueza del mismo [el concepto 'reino de Dios'] en la predicación y en la acción de Jesús, precisamente porque engloba y totaliza su misión entera hace que, por un lado, deba ser recogido en toda su complejidad y que, por otro, deba ser sometido a un permanente proceso de historización, en su doble vertiente de ver qué tiene el reino de circunstancialidad histórica y qué exige de creatividad histórica"61. El reinado de Dios es la superación de todas las situaciones que alienan al ser humano y a su interacción con la creación, como el dolor, el hambre, la injusticia, la división y el odio. Sin olvidar que ningún proyecto histórico cumple totalmente con la utopía del reino de Dios en la tierra, pero que el "jalón utópico del reino lleva a la transformación de la historia, en especial de la historia de opresión, con lo cual el reino deja de ser una meta transhistórica para convertirse en un principio histórico de efectividad real"62.

61. Ibíd., pp. 312-313.

62. I. Ellacuría, "Las bienaventuranzas, carta fundacional de la Iglesia de los pobres", óp. cit., p. 432. 


\subsection{Derechos humanos y reinado de Dios}

De la lectura de los Evangelios no se deduce directamente un sistema económico, político o social. Ellacuría insistía en que el reinado de Dios no podía coincidir con ningún sistema político y económico, pero sin negar sus dimensiones histórica y utópica que sirven, entre otras cosas, de instancias críticas para oponerse a una realidad marcada por el pecado: "[E]se reino de Dios entre los hombres, para que pueda ser mínimamente aceptable y creíble, no puede compaginarse con una situación en la cual gran parte de la humanidad, especialmente los más pobres, se ve privada no sólo de lo más necesario para su vida, sino de la posibilidad misma de mantenerse viva y de autorrealizarse libremente" ${ }^{\prime 63}$. En este sentido, se pueden establecer claves para discernir qué realidades humanizan o deshumanizan, en virtud de que el reinado de Dios tiene un sentido fundamental. Al respecto, son certeras las palabras del teólogo uruguayo Juan Luis Segundo: "Los Evangelios o, si se quiere el Nuevo Testamento, no presentan una teoría de la sociedad o especiales procedimientos para modificarla. '¡Ay de los ricos!', dijo Cristo de distintas maneras y en diferentes ocasiones. Y explicó por qué. Pero no es posible deducir de ello un sistema económico o político. Se trata de una orientación humana que rechaza el lucro como centro de la actividad del hombre $\mathrm{y}$ de sus relaciones interpersonales" ${ }^{\prime 4}$.

En esta posición coincide Ellacuría, al asumir también en su discurso teológico la contraposición entre la civilización de la riqueza y la civilización de la pobreza. El reinado de Dios está en estrecha conexión con el pueblo de Dios, como pueblo crucificado, que lucha por su liberación: “...si el reino de Dios y el reino del pecado son dos realidades opuestas, que tienen como protagonistas a hombres de carne y hueso, de los que unos ostentan el poder de dominación opresora, no podrán menos que ejercitarlo contra quienes sólo tienen el poder de su palabra y de su vida, ofrecidas por la salvación de muchos" ${ }^{\prime 65}$. Es claro que el concepto "derechos humanos" no formaba parte de la cultura a la cual pertenecía Jesús de Nazaret. Sin embargo, de su predicación y praxis, se pueden encontrar ciertas orientaciones que indican las clases de derechos que han de tener los seres humanos en la sociedad alternativa que Dios desea. Y esto es importante para la fe del cristiano de hoy porque el discurso de los derechos humanos no es neutral; si bien ha sido utilizado, como dice Ellacuría, por quienes ejercen el poder de la dominación opresora, también ha sido herramienta de quienes únicamente tienen el poder de su palabra y de su vida.

63. I. Ellacuría, "El reino de Dios y el paro en el Tercer Mundo", en Escritos teológicos, tomo II, óp. cit., pp. 295-296.

64. J. L. Segundo, De la sociedad a la teología, Ed. Carlos Lohlé, Buenos Aires, 1970, pp. 130-131.

65. I. Ellacuría, "El pueblo crucificado. Ensayo de soteriología histórica”, óp. cit., p. 147. 


\subsubsection{La perspectiva de derechos humanos}

¿Qué perspectiva de derechos humanos se puede encontrar en el Evangelio? ¿Cuál es el sentido de estos derechos acorde al mensaje y la práctica de Jesús? El interés por el ser humano en los textos evangélicos es patente, pues se presenta a un Jesús preocupado por el sufrimiento de los otros. A un Jesús que siente una enorme indignación ante las condiciones de vida de los excluidos del sistema y de los que mueren antes de tiempo. En este sentido, Marcos narra que "al bajar de la barca, vio Jesús todo ese pueblo y sintió compasión de ellos, pues eran como ovejas sin pastor" (Mc 6, 34). Compasión, según el Evangelio, no es sentir lástima por el otro, sino sentir como propio el dolor ajeno. Es el detonador que pone en movimiento a todo el ser humano ante la situación de miseria del mundo.

En la parábola del buen samaritano se encuentra una propuesta que hace el Evangelio para reflexionar sobre derechos humanos. Narrada por Lucas, esta parábola es la respuesta que da Jesús a un maestro de la Ley. La pregunta que realiza el jurista es "¿qué tengo que hacer para heredar la vida eterna?" (Lc 10, 25). Es obvio que el propio jurista sabía la respuesta, y su pregunta tan solo buscaba poner a prueba a Jesús. Este no responde directamente y opta por devolverle la pregunta: “Qué está escrito en la Ley?” (Lc 10, 26). El jurista sabía la respuesta, la cual consistía en los mandamientos de Moisés. Además, los judíos rezaban mañana y tarde en la sinagoga una oración que comenzaba con un texto del Deuteronomio: "Escucha, Israel, el Señor, nuestro Dios, es solamente uno. Amarás al Señor tu Dios con todo tu corazón, con toda tu alma, con todas tus fuerzas, con toda tu mente" (Dt 6, 4-9). Por eso Jesús completa su repregunta con “cómo es eso que recitas?”. El jurista da su respuesta según los mandamientos y el contenido de su oración, pero añade el precepto del amor al prójimo ubicado en el Levítico $(19,18)$, sabiendo perfectamente que de no hacerlo perderá fácilmente el debate con Jesús: "El maestro de la Ley contestó: Amarás al Señor tu Dios con todo tu corazón, con toda tu alma, con todas tus fuerzas, y con toda tu mente. $Y a$ tu prójimo como a ti mismo" (Lc 10, 28). Entonces, Jesús simplemente confirma lo que estaba escrito en la Ley e invita a ponerlo en práctica: "Bien contestado. Haz eso y vivirás” (Lc 10, 28). Sin embargo, no termina aquí la discusión.

El jurista, poco complacido con la actitud de Jesús, le realiza una nueva pregunta: “Y quién es mi prójimo?”. Es muy probable que, al incluir el amor al prójimo dentro del mandamiento principal de la Ley, el jurista estuviera utilizando palabras del propio Jesús ${ }^{66}$. De ahí el interés por justificarse, pues si bien había un acuerdo generalizado en cuanto al deber con el prójimo, existían diversas opiniones respecto a la amplitud de tal concepto. Los fariseos

66. $C f$. Mt 23, 34-40, donde es el propio Jesús quien responde al jurista valiéndose de Dt 6, 5 y Lv 19, 18. 
se inclinaban a excluir como "prójimos" a los no fariseos; los esenios exigían que se debía odiar a "todos los hijos de las tinieblas"; una declaración rabínica enseñaba que a los renegados "se les arroje en una fosa y no se les saque"; y una máxima popular excluía al enemigo del concepto de prójimo ${ }^{67}$. En otras palabras, el contenido de la Ley era manipulable según los intereses de cada grupo. Es entonces cuando Jesús, con una interpretación desde la realidad y a favor de la construcción del reinado, enfrenta la actitud manipuladora y legalista de la Ley que realizaba el jurista.

La parábola comienza con un hombre que viaja de Jerusalén a Jericó y es asaltado por unos bandidos que "lo desnudaron, lo molieron a palos y se marcharon dejándolo medio muerto" (Lc 10, 30). Es un hombre anónimo que queda desamparado y desnudo, sin identidad, en el borde del camino. Símbolo de las mayorías populares, del pueblo crucificado por el mundo actual. Queda vivo, pero moribundo; es prácticamente un cadáver.

La segunda escena presenta a dos personajes. El primero es un sacerdote que bajaba por ese camino, vio al hombre herido y pasó de largo. Luego, llegó un levita, también observó al herido y siguió su trayecto. Ambos personajes eran funcionarios del templo de Jerusalén y, por tanto, conocían perfectamente la Ley. Entonces, ¿por qué no se detuvieron a auxiliar al moribundo? Una probable respuesta consiste en señalar que ambos funcionarios cumplieron con una norma establecida en el libro del Levítico ${ }^{68}$ que prohibía al sacerdote y al levita todo contacto con cadáveres, excepto cuando fueran parientes cercanos. De lo cual se podría deducir que tomaron por muerto al moribundo. Para el sacerdote dicha prohibición regía en todo momento, mientras que para el levita exclusivamente antes de la celebración del culto. Sin embargo, esta hipótesis enfrenta ciertas dificultades. Por un lado, según la parábola, el levita va de Jerusalén a Jericó, lo que significa que ya había realizado el culto, ya había asistido al templo, y por tanto pudo haberse detenido para levantar al supuesto cadáver. Por otro lado, existen varios textos en el Talmud y la Mishná que contienen, a favor del sacerdote, ciertas excepciones a dicha norma cuando se trata de un cadáver abandonado en el camino, al cual nadie ha de darle sepultura. En este caso, ni el sacerdote ni el levita tenían algún impedimento legal para detenerse a tocar el supuesto cadáver.

La tercera escena consiste en el desenlace de la parábola. El nuevo personaje que entra en escena debe resolver la situación. Después de los dos funcionarios del templo, quienes escuchaban el relato esperaban que el tercer personaje fuera un laico judío. Sin embargo, el elemento sorpresivo de esta parábola consiste en la presentación de dicho personaje: "Pero un samaritano que iba de viaje llegó a donde estaba el hombre y al verlo tuvo compasión" (Lc 10, 33). Seguramente, la

67. Cf. J. Jeremias, Las parábolas de Jesús, Verbo Divino, Estella, 1991, p. 246.

68. $C f$. Lv 21, 1 y ss. 
inserción de un samaritano en la narración causó incomodidad y repulsión entre los oyentes judíos. Es bien sabida la enemistad que existía entre samaritanos y judíos en tiempos de Jesús. Según narra Flavio Josefo, estos últimos profanaron los pórticos del templo y del santuario esparciendo huesos humanos bajo el resguardo de la oscuridad nocturna, en tiempos del procurador Coponio (6-9 a. C.). Además, este odio provenía desde el siglo IV a. C., cuando los samaritanos se separaron de los judíos y construyeron su propio templo en el monte Garizín. De ahí lo sorpresivo de la identidad del tercer personaje. ¿Qué podían esperar los oyentes judíos de alguno de las tierras de Samaria? ¿Cómo podía un samaritano mostrar una actitud que concluyera con la parábola y diera respuesta a la pregunta del jurista? Pero el relato rompe con las expectativas de los oyentes. El samaritano se acercó al moribundo, le auxilió y le pagó a un posadero para que le atendiera ${ }^{69}$. Al término de la parábola, Jesús pregunta al jurista: "¿Quién de estos te parece que fue prójimo del que cayó en manos de los salteadores?" (Lc 10, 36). A lo cual contestó: "El que tuvo misericordia de él" (Lc 10, 37).

La parábola del buen samaritano da claves importantes para una visión de derechos humanos. Como primer punto, estos derechos deben entenderse como correlativos a un deber. Un derecho no es eficaz por sí mismo; es necesaria una obligación que le corresponda. La realización de derechos humanos del hombre asaltado no dependió, en última instancia, de su inherencia a la naturaleza humana, sino del cumplimiento de un deber por parte del samaritano. En cambio, los derechos humanos del hombre moribundo quedaron en mera abstracción y sin eficacia en virtud de la actitud del sacerdote y del levita; ninguno de los dos se sintió comprometido con el otro y pasaron de largo. Para Jesús, quien se hizo realmente prójimo, quien en verdad cumplió su deber con el otro, fue el samaritano. Gracias a él, tuvieron plena eficacia los derechos humanos del hombre herido. Pero para hacerlo, no tomó la actitud que el estereotipo le imponía: "El samaritano no cumple con la Ley de Moisés". Al contrario, fue el único que efectivamente llevó a la vida el mandamiento mayor. Lo mismo sucede con los procesos de derechos humanos. La ideología dominante señala que el fin último es el individuo y sus intereses, sin ninguna responsabilidad social y con total ausencia de solidaridad. Este individualismo quiere presentarse como el fundamento de una cultura de derechos humanos, pero invisibiliza la complejidad de las relaciones y luchas sociales. Contradicción insuperable desde la visión evangélica. El levita y el sacerdote, sin importar el pretexto que tuvieran, no fueron capaces de abandonar su individualismo y ser solidarios con el otro.

Como segundo punto, los derechos humanos no pueden quedarse limitados a su aspecto formal, pues rebasan los límites de la ley. Su fundamento principal no debe ser el ordenamiento jurídico, pues éste es tan sólo uno de los medios para

69. Cf. Lc 10, 34-35. 
lograr su cumplimiento. Los procesos de derechos humanos deben fundarse en el ser humano y las necesidades concretas según su naturaleza y su situación histórica. Cuando el samaritano se acercó al hombre herido no buscó en una compilación de leyes cuál era su deber jurídico, sino que observó las necesidades del moribundo y a ellas respondió a través de siete acciones: se compadeció (1), se acercó (2), le vendó las heridas (3), y las mojó con aceite y vino (4), le montó en su propia cabalgadura (5), le llevó a una posada (6), y lo cuidó (7). El simbolismo del número siete es fundamental en la Biblia. Significa la perfección, el período pleno y completo ${ }^{70}$. Por tanto, el samaritano responde de manera perfecta y plena a las necesidades de su prójimo. Pero no se quedó ahí, sino que fue más allá: al día siguiente da al posadero dos denarios para que cuide al malherido, y si gasta más, le dice que se lo pagará a la vuelta (Lc 10, 35). En efecto, la reflexión de derechos humanos no puede quedarse en atenuar las necesidades actuales, sino que debe llegar hasta el extremo de lo imaginable y pensar también en la superación de dichas necesidades en el futuro: "Al día siguiente sacó dos denarios de plata y, dándoselos al posadero, le pidió que cuidara del herido...”. Es parte de la faceta utópica de derechos humanos en que insiste Ellacuría.

Como tercer punto, previo a cualquier desarrollo teórico, los Evangelios presentan la experiencia que debe ser el fundamento para determinar el contenido de derechos humanos: la realidad en que vive el pueblo crucificado. A partir de sentir esta realidad se debe desarrollar la teoría sobre derechos humanos, pues solo así tendrá consecuencias prácticas. Si no se piensan estos derechos desde las realidades de injusticia, es fácil caer en el error de considerarlos como algo previo a la acción humana que construye las estructuras sociales, de afirmarlos como meras categorías normativas que existen en un mundo ideal que están en espera de ser puestas en práctica. Pero desde la realidad de pobreza, desde esa realidad por la cual Jesús se compadeción ${ }^{71}$, se cae en la cuenta de que derechos humanos se van creando y recreando en virtud de la lucha por modificar las estructuras sociales. El levita y el sacerdote conocían perfectamente el contenido

70. Cf. diversos textos con el simbolismo del número siete: Gn 4, 15; Gn 10; Zac 4, 10; Sal 90, 10; Mc 8, 5; Mt 12, 45; Lc 8, 2; Mt 22, 25; Mt 18, 21-22; Lc 10, 1; entre otros.

71. Es importante tener en cuenta que "el término 'compasión', sin embargo, es todavía demasiado inexpresivo para reflejar la emoción que movía a Jesús. El verbo griego esplagjnizomai, usado en todos estos textos, se deriva del sustantivo esplagjnon, que significa vientre, intestinos, entrañas, corazón, es decir, las partes internas de donde parecen surgir las emociones profundas. El verbo griego, por consiguiente, indica un movimiento o impulso que fluye de las entrañas, una reacción visceral. Por eso los traductores han recurrido a expresiones como 'se sintió movido de compasión o lástima', 'sintió pena' o 'su corazón se derramó hacia ellos'. Pero ni siquiera estas expresiones captan las profundas connotaciones físicas y emotivas de la expresión griega para referirse a esa compasión” (A. Nolan, ¿Quién es este hombre? Jesús, antes del cristianismo, trad. de Jesús García-Abril, Sal Terrae, Santander, 1981, p. 50). 
de la Ley de Moisés; eran conscientes del mandamiento del amor a Dios y al prójimo. Pero no sintieron compasión por el malherido, y por eso no fueron capaces de percatarse de sus carestías. Sólo el samaritano se compadeció de él y respondió a sus necesidades. Si se preguntara a los tres personajes respecto a los derechos humanos del hombre asaltado, seguramente el que respondería de forma acertada sería el samaritano, pues fue el único que sintió compasión.

Como cuarto punto, y muy relacionado con los anteriores, pensar los derechos humanos desde las víctimas permite realizar una reflexión que responda a los escenarios actuales. Mantenerse alejado de las múltiples y diversas situaciones de pobreza, miseria y opresión provoca que la conceptualización de derechos humanos pierda coherencia con la realidad. El samaritano respondió de manera plena y perfecta a las necesidades del malherido porque se acercó y sintió compasión, y no enfrentó la realidad como lo hicieron el levita y el sacerdote que, debido a su lejanía, probablemente creyeron que el hombre estaba muerto, y que su único derecho consistía en ser sepultado.

\subsubsection{Derechos humanos como derechos de los oprimidos}

Ellacuría afirma que "los derechos humanos deben ser primariamente derechos de los oprimidos, pues los opresores no pueden tener derecho alguno, en tanto que opresores, y a lo sumo tendrán el derecho a que se les saque de su opresión. Solo haciendo justicia a los pueblos y a las clases oprimidas se propiciará su auténtico bien común y los derechos humanos serán realmente universales" 72 . Esta perspectiva de los derechos humanos como derechos de los pobres y oprimidos no solo tiene, en el pensamiento de Ellacuría, un fundamento filosófico, sino también teológico.

El reinado de Dios es una buena noticia para los pobres, como ya se ha dicho; sin embargo, ¿qué entiende la teología de la liberación por "pobres"? La aclaración de este concepto es fundamental, pues, para aligerar el contenido del mensaje cristiano, se le ha presentado de manera moralizante. En cierta manera, al hablar del pueblo crucificado hemos abordado indirectamente el sentido de "pobre". Ellacuría desarrolla este concepto en sus diversas facetas: socioeconómica, dialéctica, política, ética y teológica.

Los pobres son, en primer lugar, los que tienen este carácter por su materialidad, que es un elemento real insustituible. Es una materialidad que no puede ser sustituida por ninguna espiritualidad que niegue el carácter de "analogado principal" del concepto socioeconómico. Son pobres los que carecen de bienes fundamentales, "sea en referencia a lo que es un mínimo aceptable, en una deter-

72. I. Ellacuría, "Historización del bien común y de los derechos humanos en una sociedad dividida", en Escritos filosóficos, tomo III, UCA Editores, San Salvador, 2001, p. 223. 
minada sociedad, sea en referencia a otras personas o grupos sociales, que son considerados ricos"73. En segundo lugar, Ellacuría establece el carácter dialéctico de los pobres y de la pobreza. En este sentido, pobre no es solo el que carece de algo, sino el que es privado; consiste "en estar desposeído dialécticamente del fruto de su trabajo y del trabajo mismo, así como del poder social y político, por quienes, con ese despojo, se han enriquecido y se han tomado el poder" ${ }^{\text {"74 }}$. Esta situación dialéctica de la pobreza, donde los bienes son aprovechados inequitativamente, pero que además la riqueza se construye en función de la explotación, exclusión y despojo de los pobres, es un elemento decisivo para comprender lo que son los pobres como lugar teológico en América Latina. Y para Ellacuría, este aspecto dialéctico de la pobreza es algo que muestra la predicación cristiana y no necesariamente se requiere del análisis marxista. En tercer lugar, los pobres son en sí mismos una fuerza política, pues en América Latina, ellos se constituyen como sujetos de su propia historia. En cuarto lugar, es un concepto ético porque su realidad no depende tanto de factores naturales como de factores históricos; en este sentido, la pobreza "tiene que ver con el bien y el mal, con la justicia y la injusticia, con la realización del hombre y la estructura social"75.

En cuanto al concepto teologal, Ellacuría establece algunas diferencias entre los pobres bíblicos y las clases oprimidas. Aunque entre ambas categorías hay semejanzas, no se identifican por varias razones $^{76}$ : (a) el concepto de pobre bíblico es más amplio que las clases oprimidas y, en concreto, no puede identificarse con el proletariado estrictamente entendido; (b) la especial preferencia de Dios por los pobres no se reduce a su liberación puramente socioeconómica, sino que atiende a su condición personal y a su liberación histórico-transcendente; (c) los pobres de Yahvé no se reducen a ser una categoría sociohistórica, aunque son una realidad histórica; (d) los pobres han de incorporar el espíritu del mensaje cristiano de modo que sean auténticamente pobres con espíritu, es decir, pobres que se constituyan como sujetos de su liberación; (e) las luchas revolucionarias de las clases oprimidas no son suficientes ni para la liberación integral, ni siquiera para la liberación exclusivamente histórica, aunque existan tramos coincidentes; y (f) esta coincidencia no pasa por la dictadura del proletariado, ni por la toma del poder, como se ha comentado.

Ellacuría habla de pobres con espíritu, es decir, "habría que hablar de conciencia de la propia condición de pobreza, pero de una conciencia activa que,

73. I. Ellacuría, "Pobres”, en Escritos teológicos, tomo II, óp. cit., p. 174.

74. I. Ellacuría, “Los pobres, 'lugar teológico’ en América Latina”, óp. cit., p. 144.

75. I. Ellacuría, "Pobres”, óp. cit., p. 176.

76. $C f$. I. Ellacuría, "Teología de la liberación frente al cambio socio-histórico en América Latina”, óp. cit., p. 337. 
apoyada en la realidad de la pobreza, la dinamice y la oriente"77. Son pobres que asumen su pobreza real, con su potencialidad humana y cristiana, desde la perspectiva del reinado. Esta espiritualidad de la pobreza cristiana es, ante todo, "una toma de conciencia sobre el hecho mismo de la pobreza material, una toma de conciencia individual y colectiva"78, la cual pasa por lo que la dialéctica pobrezariqueza tiene de injusticia e insolidaridad; cristianamente pasa por darse cuenta de lo que tiene de pecado, y que hace imposible la realización histórica del reinado de Dios. Además, esta conciencia debe de convertirse en praxis de liberación. Esto requiere de una organización popular, donde los pobres, en cuanto pobres, se organicen para iniciar un proceso de liberación que haga desaparecer la dialéctica riqueza-pobreza. En efecto, estos pobres con espíritu historizan el escándalo de que el Siervo de Yahvé, el pueblo crucificado, que es despreciado y humillado, es quien traerá la salvación y la liberación: "Una revolución hecha desde los pobres, con ellos y para ellos, se convierte así, 'escandalosamente', en un nuevo signo fundamental del reino de Dios que se acerca, porque está ya entre nosotros; signo fundamental de un reino de Dios que busca y va logrando operativizarse en la historia. La buena nueva predicada a los pobres como sujetos primarios de su propia historia y de cada una de las historias nacionales"79.

Los pobres son sujetos de derechos; capaces de constituirse en subjetividades emergentes que luchan por su autorrealización. No reconocer esto sería ir contra una de las nociones fundamentales de la construcción del reinado de Dios: que este se realiza desde los pobres. Como señala Ellacuría, son "dos cosas distintas reconocer que en los pobres, como estatuto social mayoritario del mundo, se compruebe empíricamente un enorme potencial de liberación y afirmar que ellos son los elegidos por Dios para ser los salvadores de la humanidad. Son los salvadores porque son los condenados por este mundo de pecado y porque son los elegidos por libre y gratuita iniciativa del Dios cristiano. Si se comprueba empíricamente su potencial liberador — cosa que temen los ricos y poderosos de este mundo-, en ello se ve la comprobación indirecta y eficaz de la promesa de Dios" $"$. Así, por ejemplo, la promoción de un supuesto derecho a la libertad que ocasione la desigualdad y el desempleo no es un derecho humano; probablemente, sea un privilegio de los poderosos y de los amos del capital, los únicos que en la lógica del mercado son auténticamente libres. En efecto, señala Ellacuría que "el reino de Dios, a pesar de lo que digan los hombres de la Ilustración europea, no es sin más el 'reino de la libertad', sino que es más bien el 'reino de la justicia y de la fraternidad', en el cual se busca servir más que ser servido, en el cual se

77. I. Ellacuría, "Las bienaventuranzas, carta fundacional de la Iglesia de los pobres", óp. cit., p. 424.

78. I. Ellacuría, “Los pobres, 'lugar teológico’ en América Latina”, óp. cit., p. 145.

79. Ibid., pp. 143-144.

80. I. Ellacuría, "Iglesia como pueblo de Dios", óp. cit., p. 328. 
busca ser el último de los hermanos, en el cual se tienen grandes reservas contra todas las formas de poder" $"$.

Sin condiciones materiales para poner en práctica las libertades individuales, ni la libertad ni la igualdad tienen cabida en el sistema. Es necesario otro tipo de relaciones de producción y distribución de los bienes, como lo propone Ellacuría a través de su concepto de la "civilización de la pobreza", pues los actuales problemas de desempleo y pobreza en América Latina, y en todo el Tercer Mundo, exhiben la incoherencia entre el discurso sobre derechos humanos y la realidad. "Si la libertad ha de entenderse como plenitud de la vida, la libertad ha de comenzar como liberación de la muerte" ${ }^{\$ 2}$.

\section{Conclusión}

Una lectura de la teología de Ellacuría, desde una sensibilidad de derechos humanos, nos muestra la manera en que los derechos de los pobres son parte constitutiva de la construcción del reinado de Dios. En este sentido, los derechos humanos se comprenden como herramientas jurídicas para salvaguardar la vida, el trabajo, la libertad, la igualdad y la cultura de los oprimidos. Su vigencia, por tanto, solo es posible si se tiene el objetivo de reparar las injusticias y permitir que los más pobres se constituyan en sujetos que reivindiquen la producción de su vida.

Lo señalado a través de estas páginas nos lleva a sostener, siguiendo a Ellacuría, que "[m]ientras haya pobres, la liberación vendrá de los pobres" ${ }^{83}$. Es decir, mientras existan pobres, los derechos humanos deberán de ser reinventados, renovándolos dentro de las diversas praxis de liberación, para evitar que sean ideologizados y utilizados como instrumentos de opresión. Así, los derechos humanos se ubican en la frontera del derecho, y se constituyen en una instancia crítica bajo el supuesto de que todo sistema (jurídico, político, económico, etc.) finalmente llegará a crear víctimas. Son estas víctimas, que constituyen el siervo de Yahvé y el pueblo de Dios, quienes al constituirse como pobres con espíritu inician procesos de derechos humanos. Y estos procesos pueden evitar que los sistemas jurídicos — por más perfectos que se presuman ser — se petrifiquen y se vuelvan estáticos y cerrados en sí mismos, e impulsar, entonces, su dinamicidad y renovación para que en verdad el sábado sirva al ser humano y no el ser humano sirva al sábado.

81. I. Ellacuría, “Los pobres, 'lugar teológico’ en América Latina”, óp. cit., p. 147.

82. I. Ellacuría, "Aporte de la teología de la liberación a las religiones abrahámicas en la superación del individualismo y del positivismo", óp. cit., p. 216.

83. I. Ellacuría, "En torno al concepto y a la idea de liberación”, óp. cit., p. 645. 